\title{
The Query of Suitable Areas for plantation and development of Taxus baccata L Species by Using GIS in Northern Iran
}

\author{
ANOSHIRVAN ALAMI ${ }^{1}$, ALIREZA ESLAMI ${ }^{2}$ and SEYED A. HASHEMI ${ }^{3}$ \\ ${ }^{1}$ Department of Forestry, Science and Research Branch, Islamic Azad University, 4194151479, Guilan, Iran \\ ${ }^{2}$ Department of Agriculture, Rasht Branch, Islamic Azad University, 413353516, Rasht, Iran \\ ${ }^{3}$ Department of Forestry, College of Natural Resources, Lahijan Branch, Islamic Azad University, University, 4416939515, Lahijtan, Iran
}

Manuscript received on March 20, 2013; accepted for publication on October 28, 2013

\begin{abstract}
Taxus baccata is a native species to the Caspian forests and is considered as the identification of these forests by some resources. The aim of this study was to understand the ecological characteristics of $T$. baccata in order to find suitable areas for its plantation in the Pone Aram preserve of Golestan province. Therefore, Multi-Criteria Evaluation (MCE) methods based on Analytical Hierarchy Process (AHP) were used. In this process at first the needed and effective natural indexes were used as 10 parameters. Then the final map of suitable areas for T. baccata plantation were produced based on Bolian and MCE models. According to the results, in Bolian method about 6218 ha of the total area of the study site (30554 ha) were estimated as suitable and semi suitable and 24336 ha were estimated as unsuitable for MCE model showed that about 2482 ha of the whole 30554 ha area of the study site is adequate for T. baccata plantation and 6181 ha is not adequate for T. baccata plantation. Regarding the results of the MCE and Bolian methods it has been concluded that for dynamic ecological parameters in delineation of suitable areas for T. baccata plantation the MCE weighting is more appropriate than Bolian. Using the results of this investigation it is possible to adequate areas for the presence of T. baccata and to execute a plan in order to facilitate the plantation of T. baccata in northern forests of Iran (watershed 88).
\end{abstract}

Key words: Taxus baccata, locating, MCE, Bolian, Pone Aram, Iran.

\section{INTRODUCTION}

Taxus baccata is classified as a conifer in the order Pinales, family Taxaceae and genus Taxus. Three species of genus Taxus are found in Iran of which only T. baccata is native (Yazdani et al. 2005). T. baccata is an evergreen species with high longevity, slow growth, straight stem and Sinusoidal profile and may reach the height of $30 \mathrm{~m}$ and the diameter of $2.5 \mathrm{~m}$ (in

Correspondence to: Alireza Eslami

E-mail: dr_eslami2006@yahoo.com
Siyahkal) (Ahmadi et al. 2011, Poorbabaei et al. 1998). Its crown is extended and semi-spherical. The bark is scaly, laminated and reddish brown. The leaves are thin and long, with spiral arrangement, upper surface of the lamina is dark green and glossy but the lower surface is light green. Reach 2-3 its width 2-3mm. Flowers are without petal and sepal and appear as female and male on separate female and male trees. Its fruit is called aril and is berry-like, red, sweet and edible. Its annual height growth has been 
estimated about $10 \mathrm{~cm}$ and annual diameter growth is about $0.5 \mathrm{~mm}(0.64 \mathrm{~mm}$ of average annual diameter growth) (Lessani 1999, Danehkar and Mahmoodi 2008, Dargahi 2000). T. baccata is shade tolerant and is able to continue its physiological activities despite low light conditions. Its reproduction is by seed under $2.5 \mathrm{~cm}$ of light soil or by grafting in autumn. Stand mixture plays an important role in preservation and reclamation of T. baccata stands. Slow growth, long and irregular seeding period, wood quality, leaves toxicity to livestock etc. are the reason of its degradation and endangerment. $T$. baccata dates back to 190 million years ago and its oldest fossils are related to the Miocene and the Pliocene. T. baccata species is found in most European countries including England, southern Norway, and southern Sweden to $60^{\circ} \mathrm{N}$ latitudes, Baltic countries and Alps mountain up to $1400 \mathrm{~m}$ above sea level, Carpathian mountain, Caucasus, Turkey, northern Iran, northern Africa and partially scattered in other locations. The lowest altitude of its appearance is in Havigh near Talesh (220m a. s. 1.) and Filbak Saray forest in Langrood $(270 \mathrm{~m}$ a. s. 1.) (Poorbabaei et al. 1998) and the highest altitude of its appearance is in Ali Abad Katool forest (1800m a. s. 1.) (Habib Kaseb and Lessani 1985, Delavar 1980, Emami et al. 2004, Verdian 2004). Some T. baccata specimens were observed in Arasbaran forests by Javanshir (1994). During the 1960s, the National Cancer Institute of the U.S. started investigations on anti cancer effects of plants and finally found Taxol. Taxol is the commercial name of the substance Paclitaxel which was tested for the first time in 1977 and approved by the FDA for cervical, breast and Kaposi's sarcoma cancers. This investigation aims to delineate adequate areas for T. baccata plantation and development in Golestan province, northern Iran (watershed 88) through locating the natural habitat of this species and also to study the possibility of its plantation by collecting mentioned data and merging them regarding the effectiveness of each part using GIS.

\section{MATERIALS AND METHODS}

STUDY AREA

Watershed 88 with borders between Ali Abad and Ramian counties. The study area with the area of about 30554ha is located between N $36^{\circ} 44^{\prime}$ '08" to $36^{\circ} 55^{\prime} 32^{\prime \prime}$ and E $54^{\circ} 50^{\prime} 06^{\prime \prime}$ to $55^{\circ} 09^{\prime} 42^{\prime \prime}$. The elevation ranges from $119 \mathrm{~m}$ to $2570 \mathrm{~m}$ a. s. 1 . The whole area covers four forest management plans inclusive of Rezaeian (compartments 1, 2, 3 and 4), Sorkhdari (compartments 1 and 2), ZarrinGol and Kaboodval. In addition nature preserve of Pune Aram and Afra Takhte are within the area.

METHOD

First step: to collect the existing statistics and information

In this stage a database was created inclusive of digitized topographic maps, images of $\mathrm{TM}+$ satellite taken in 2010 provided by Golestan Povince General Office of Natural Resources and Watershed Management, and also collecting some data about annual precipitation, annual temperature, the relative humidity of air, soil type, type and density of vegetation cover and lithology. One of some of the resources used, were maps and executive and feasibility study reports of the forest management plans in the watershed 88 (Kaboodval, Rezaeian, Zarrin Gol and Sorkhdari) produced by Golestan Povince General Office of Natural Resources and Watershed Management during 2008-2010.

\section{Second step: field works}

The map of the location of T. baccata preserves was created using GPS. Then weighting was done based on the T. baccata presence in each class of the map.

\section{Third step: information analysis and presenting} the results

In this step analysis and data collection and also parameters weighting based on the paired comparison in the AHP were done and subsequently adequate areas for the presence were identified as 4 classes. 


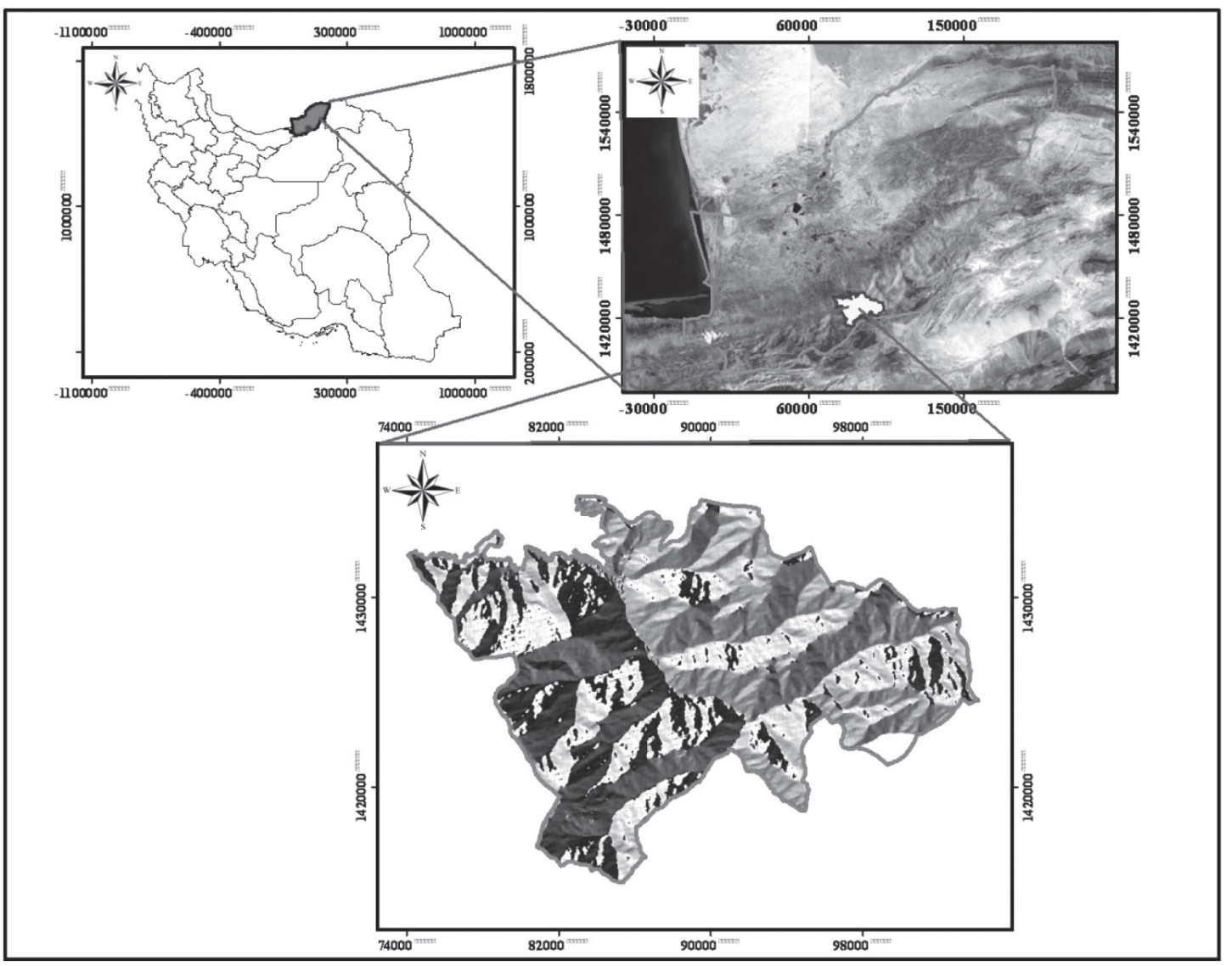

Figure 1 - Study site location in Golestan Province and Iran.

Then $T$. baccata locating was separated in two classes: Adequate and Inadequate. In order to combine the maps the Bolian logic based on function "And" was used. For combining the maps with relational models, ranking and the AHP, final maps were produced from combined maps (sum function) (Parhizkar and Ghaffari Gilandeh 2006). In the end the results of these two methods were compared. In recent years some models with the ability of providing accurate spatial information were developed using the GIS. The process stages: recognition, providing needed data, determining the effective factors, accurate recognition of study area, data collecting, preparing map and producing the output maps. An important thing in locating is the extraction of environmental factors and their classification to several effective parts that requires the accurate recognition of the importance of each factor.
RESULTS

The Results of Bolian Method In LOCATING T. baccata

Each map the locations with adequate of T. baccata presence valued as 1 and the location inadequate of T. baccata valued as 0 .

Elevation: after producing the Bolian map of elevation it was revealed that the richest elevation class of T. baccata presence is $1200-1600 \mathrm{~m}$ a. s. 1 . with an area of 8591 ha and the biggest area without T. baccata presence possibility was 5058 ha at the elevation class of 400-800 m a. s. 1 .

Slope: producing the Bolian map of slope it was noted that the richest slope class of T. baccata presence was slope class of $25-50 \%$ with the area of 14610 ha and the greatest area without $T$. baccata presence possibility is $430 \mathrm{ha}$. 
Slope aspect: producing the Bolian map of slope aspect it was noted that the richest slope aspect class of $T$. baccata presence was northern slope aspect class with the area of 6524ha and the greatest area without $T$. baccata presence possibility was eastern slope aspects with 2324 ha area.

Soil type: the soil type map was also created using Bolian method based on presence and absence of $T$. baccata. The biggest area of a soil type with the most $T$. baccata presence was the type 1.2.1 with the area of 9371ha and the largest area without $T$. baccata inadequate was related to the soil type 1.1.2 with 3884ha area.

Geology: The geological map was also produced using Bolian method based on presence and absence of $T$. baccata. The greatest area of $T$. baccata presence was related to the CM formation with 11899ha area and the greatest area without $T$. baccata adequate was related to the Qs.d formation with the area of 1531 ha.

Relative humidity: the map of relative humidity was also created using Bolian method based on presence and absence of $T$. baccata. The greatest area of $T$. baccata adequate was related to the class 70.33-70.69 with 6689ha area and the greatest area without $T$. baccata adequate was in the class 70.6971.05 with the area of 6531 ha.

Annual precipitation: the map of annual precipitation was produced using Bolian method based on presence and absence of T. baccata. The greatest area of $T$. baccata adequate was related to the class $560-640 \mathrm{~mm}$ with $11461 \mathrm{ha}$ area and the greatest area without $T$. baccata presence was related to the precipitation class of more than $720 \mathrm{~mm}$ with the area of 2368 ha.

Temperature: the map of annual temperature was also produced using Bolian method based on presence and absence of $T$. baccata. The greatest area of $T$. baccata adequate was related to the class $17-17.80^{\circ} \mathrm{C}$ with $14637 \mathrm{ha}$ area and the greatest area without $T$. baccata presence was related to the class $17.80-18.60^{\circ} \mathrm{C}$ with the area of $5216 \mathrm{ha}$.
Tree cover type: the map of tree cover type was created using Bolian method based on presence and absence of T. baccata. The greatest tree cover type area of $T$. baccata adequate was in the type Carpineto-Quercetum with 8363 ha area and the greatest area without $T$. baccata presence was related to the type Parrotio-Carpinetum with the area of $2100 \mathrm{ha}$.

Vegetation canopy cover density: the map of vegetation canopy cover density was created using Bolian method based on presence and absence of $T$. baccata. The greatest area of T. baccata adequate in the vegetation canopy cover density classes was related to the class of more than $80 \%$ with 15171 ha area and the greatest area without $T$. baccata presence was related to the class of $20-40 \%$ with the area of 1321ha.

RESULTS OF MCE METHOD FOR LOCATING T. baccata

Score layer of T. baccata locating by AHP

The effective factors on T. baccata locating were weighted using paired comparisons of Expert Choice 11 software by 4 academic staff specialists and 1 executive specialist (Table I). According to the experts opinions the effective factors were weighted as follow: precipitation classes $=0.100$, slope classes $=0.084$, lithology classes $=0.039$, aspect classes $=0.110$, relative humidity classes $=0.135$, soil type classes $=0.083$, tree cover type classes $=0.059$, vegetation canopy cover density classes $=0.147$, elevation classes $=0.146$ and temperature classes $=0.097$. Therefore vegetation canopy cover density has been identified as the most important factor with the weight of 0.147 . An important note about paired matrix is that the amount of incompatibility rate must be less than 0.1 (Sabeti 1994). The amount of incompatibility rate in this research is 0.054 which means a high compatibility.

Elevation: after weighting of the produced elevation classes it was revealed that the maximum weight or the most appropriate elevation class 
TABLE I

Weighting of $T$. baccata environmental factors by AHP method.

\begin{tabular}{cccccccc}
\hline No. & Expert parameter & $\begin{array}{c}\text { Forest } \\
\text { expert }\end{array}$ & $\begin{array}{c}\text { PhD of } \\
\text { Forestry }\end{array}$ & $\begin{array}{c}\text { PhD of } \\
\text { Forestry }\end{array}$ & $\begin{array}{c}\text { PhD of } \\
\text { Forestry }\end{array}$ & $\begin{array}{c}\text { PhD of } \\
\text { Forestry }\end{array}$ & Mean \\
\hline 1 & Slope aspect & 0.132 & 0.082 & 0.151 & 0.114 & 0.073 & 0.110 \\
2 & Slope & 0.053 & 0.098 & 0.151 & 0.069 & 0.049 & 0.084 \\
3 & elevation & 0.158 & 0.148 & 0.151 & 0.149 & 0.122 & 0.146 \\
4 & vegetation canopy cover density & 0.105 & 0.110 & 0.249 & 0.126 & 0.146 & 0.147 \\
5 & Relative humidity & 0.132 & 0.131 & 0.097 & 0.148 & 0.171 & 0.135 \\
6 & Temperature & 0.105 & 0.114 & 0.067 & 0.103 & 0.098 & 0.097 \\
7 & Precipitation & 0.105 & 0.099 & 0.043 & 0.105 & 0.147 & 0.100 \\
8 & tree cover type & 0.026 & 0.102 & 0.064 & 0.054 & 0.049 & 0.059 \\
9 & Soil & 0.105 & 0.083 & 0.014 & 0.090 & 0.122 & 0.083 \\
10 & Lithology & 0.079 & 0.033 & 0.014 & 0.043 & 0.024 & 0.039 \\
\hline Total & & $\mathbf{1}$ & $\mathbf{1}$ & $\mathbf{1}$ & $\mathbf{1}$ & $\mathbf{1}$ & $\mathbf{1}$ \\
\hline Incompatibility & & $\mathbf{0}$ & $\mathbf{0 . 1}$ & $\mathbf{0 . 0 9}$ & $\mathbf{0 . 0 8}$ & $\mathbf{0}$ & $\mathbf{0 . 0 5}$ \\
\hline rate & & & & & &
\end{tabular}

was $1200-1600 \mathrm{~m}$ a. s. 1 . and the minimum weight or the most inappropriate elevation class was the elevation class of less than $400 \mathrm{~m}$ a. s. 1 .

Slope: after weighting of the produced slope classes it was found that the maximum weight or the most appropriate slope class was $25-50 \%$ and the minimum weight or the most inappropriate class was the slope class of more than $100 \%$.

Slope aspect: after weighting of the produced slope aspect classes it was found that the maximum weight or the most appropriate slope aspect class was the northern slope and the minimum weight or the most inappropriate class was eastern slope.

Lithology: after weighting of the produced lithology classes it was cleared that the maximum weight or the most appropriate Lithology class was the dckh formation and the minimum weight or the most inappropriate class was the Qs.d formation.

Relative humidity: subsequent to weighting of the produced relative humidity classes it was found that the maximum weight or the most appropriate relative humidity class was $69.97-70.33 \%$ and the minimum weight or the most inappropriate class was $70.69-71.05 \%$.
Precipitation: after weighting of the produced precipitation classes it was found that the maximum weight or the most appropriate precipitation class was $560-640 \mathrm{~mm}$ and the minimum weight or the most inappropriate class was the precipitation class of more than $720 \mathrm{~mm}$.

Temperature: after weighting of the produced temperature classes it was found that the maximum weight or the most appropriate temperature class was $17-17.80^{\circ} \mathrm{C}$ and the minimum weight or the most inappropriate class was the temperature class of more than $19.5^{\circ} \mathrm{C}$.

Soil type: after weighting of the produced soil type classes it was revealed that the maximum weight or the most appropriate class was the type 1.1.1 and the minimum weight or the most inappropriate class was the type 2.1.3.

Vegetation canopy cover density: subsequent to weighting of the produced vegetation canopy cover density classes it was found that the maximum weight or the most appropriate class was related to the density class of more than $80 \%$ and the minimum weight or the most inappropriate class was the density class of less than $20 \%$. 
Tree cover type: after weighting of the produced treecovertype classes itwas revealed that the maximum weight or the most appropriate class was related to the type $T$. baccata and the most inappropriate class was related to the type Parrotio-Zelkovetum.

\section{DISCUSSION}

\section{The FinAl MaP RESUlted From Bolian METHOD}

The final map resulted from Bolian method= (Bolian map of precipitation classes $) \times$ (Bolian map of slope classes $) \times($ Bolian map of lithology classes $)$ $\times$ (Bolian map of slope aspect classes $) \times($ Bolian map of relative humidity classes $) \times($ Bolian map of soil type classes $) \times($ Bolian map of tree cover type classes $) \times($ Bolian map of vegetation canopy cover density classes $) \times($ Bolian map of elevation classes $)$ $\times$ (Bolian map of temperature classes).

TABLE II

Distribution of $T$. baccata locating classes using Bolian method.

\begin{tabular}{cccc}
\hline $\mathbf{N}^{\mathbf{0}}$ & Class & Area (ha) & Percentage of the area \\
\hline 1 & Inadequate & 24336 & 79.65 \\
2 & Adequate & 6218 & 20.35 \\
\hline Total & & $\mathbf{3 0 5 5 4}$ & $\mathbf{1 0 0}$ \\
\hline
\end{tabular}

ANALYSIS OF T. baccata EVALUATION RESULTS BY

BOLIAN METHOD

The result of location using Bolian method showed that the maximum area of $T$. baccata adequate is related to the elevation class of $1200-1600 \mathrm{~m}$ a. s. 1 . and the maximum area of $T$. baccata inadequate is related to the elevation class of $400-800 \mathrm{~m}$ a. s. 1 . Also the most typical part of the study area (Pone Aram) is located at the elevation of 1300 to $1470 \mathrm{~m}$ a. s. 1 . which is in accordance with the results of this study.

Between the slope map with $T$. baccata locating by Bolian method showed that slope class of $25-50 \%$ and the maximum area of $T$. baccata inadequate is related to the slope class of more than $100 \%$. The maximum area of T. baccata adequate is related to the northern slope class and the maximum area of $T$. baccata absence possibility is related to the eastern slope class. The aforementioned result is in agreement with the results of Esmailzadeh and Hoseini (2006) that they found significant difference among plant ecological groups due to physiographic factors of elevation, slope and slope aspect.

The maximum distribution of $T$. baccata is related to the precipitation class of $560-640 \mathrm{~mm}$ and the maximum area of T. baccata absence possibility is related to precipitation class of more than $700 \mathrm{~mm}$. Also the maximum area of $T$. baccata adequte is related to temperature class of $17-17.80^{\circ} \mathrm{C}$ and the maximum area of $T$. baccata inadequate is related to temperature class of $17.80-18.60^{\circ} \mathrm{C}$. In relation to the relative humidity the maximum area of $T$. baccata adequate estimated to occur in the class of $69.97-70.33 \%$ and the maximum area of T. baccata inadequate in $70.69-71.05 \%$.

After overlapping the maps from Bolian method with lithologic map the maximum area of T. baccata adequate has been estimated to be in the $\mathrm{Pd}$ formation and the maximum area of T. baccata inadequte estimated to occur in Qs.d formation.

The biggest area of a soil type with the most $T$. baccata presence was the type 1.2.1 and the largest area without $T$. baccata inadequate was related to the soil type 1.1.2.

The greatest area of $T$. baccata presence possibility in the vegetation canopy cover density classes was related to the class of more than $80 \%$ and the biggest area without $T$. baccata presence was related to the class of $20-40 \%$. Also the greatest tree cover type area of T. baccata adequate was in the type Carpineto-Quercetum and the greatest area without $T$. baccata presence was related to the type Parrotio-Carpinetum.

\section{THE FINAL MAP RESUlTEd FROM MCE METHOD}

In order to locate T. baccata species by MCE model the weight of each factor multiplied by its rate map and appropriate locations map for T. baccata 
plantation was classified in 4 classes by summing the multiplied results of factors map and turning points of cumulative frequency of pixels (Figure 2 and Table III).

The final map resulted from MCE method= (rate map of precipitation classes $\times 0.100)+($ rate map of slope classes $\times 0.084)+($ rate map of lithology classes $\times 0.039)+($ rate map of slope aspect classes $\times 0.110)+($ rate map of relative humidity classes $\times$ $0.135)+($ rate map of soil type classes $\times 0.083)+$ (rate map of tree cover type classes $\times 0.059)+($ rate map of vegetation canopy cover density classes $\times$ $0.147)+($ rate map of elevation classes $\times 0.146)+$ (rate map of temperature classes $\times 0.097$ ).

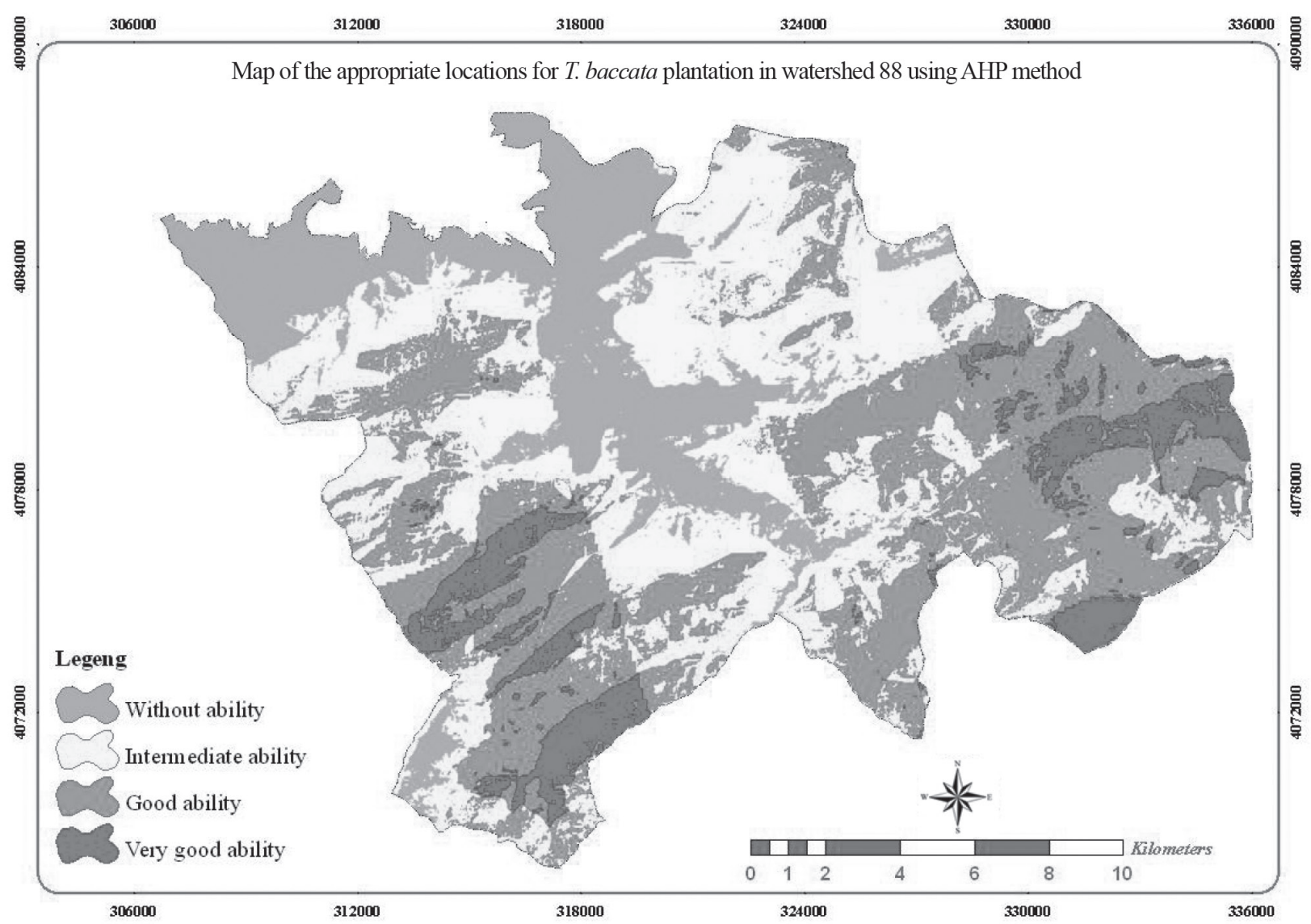

Figure 2 - Map of T. baccata locating classes using AHP method.

TABLE III

Distribution of T. baccata locating classes using AHP method.

\begin{tabular}{cccc}
\hline No. & T. baccata growth & Area (ha) & $\begin{array}{c}\text { Percentage of } \\
\text { the area }\end{array}$ \\
\hline 1 & poor & 6181 & 20.22 \\
2 & Average & 10909 & 35.69 \\
3 & Good & 10982 & 35.96 \\
4 & Very good & 2482 & 8.13 \\
\hline Total & & $\mathbf{3 0 5 5 4}$ & $\mathbf{1 0 0}$ \\
\hline
\end{tabular}


ANALYSIS OF T. baccata LOCATION EVALUATION RESULTS BY MCE METHOD

The results of weighting by AHP method showed that the maximum weight was related to vegetation canopy cover density also the parameter of lithology had the least weight. These results confirm that lithology is a low impact factor in locating this species.

By overlapping the map produced from MCE method with maps of used parameters it was found that $T$. baccata adequate in the elevation class of $1200-1600 \mathrm{~m}$ a. s. 1 . will have the maximum area and in elevation class of less than $400 \mathrm{~m}$ a. s. 1 . will has the least one. Also by overlapping the map of slope aspect classes it has been found that the northern slope has the largest area from the ability class of very good and also has the most amount of T. baccata adequate, while the areas with no slope (flat) and also eastern and south eastern slope classes cannot be classified in the class of "very good ability".

Overlapping the map produced by MCE method with the maps of slope classes showed that the slope class of $25-50 \%$ has the most amount of T. baccata adequate (very good ability) and the slope class of more than $100 \%$ has the least. Also Pd formation had the highest level in very good ability class, and Qs.d formation had the least T. baccata adequate.

The vegetation canopy cover density class of more than $80 \%$ has the most amount of $T$. baccata adequate in the ability class of good while the vegetation canopy cover density class of less than $20 \%$ is $T$. baccata inadequate in classes of good and very good.

Tree cover type of Carpinetum-betulae has the highest possibility of T. baccata presence.

Overlapping the map produced by $\mathrm{MCE}$ method with the maps of relative humidity classes showed that the class of $69.97-70.33 \%$ has the most areas of T. baccata adequate and the class of 70.6971.05 has T. baccata inadequate.

Also precipitation class of $560-640 \mathrm{~mm}$ has the most amount of $T$. baccata presence possibility while the class of more than $720 \mathrm{~mm}$ has the most amount of areas without $T$. baccata growth ability.
Temperature class of $17-17.80^{\circ} \mathrm{C}$ has the most amount of $T$. baccata adequate in the ability class of very good and the class of more than 19.5 has most area $T$. baccata inadequate.

Soil type of 1.1.1 has the most amount of T. baccata adequate in the ability class of very good while the type 2.2.2 has most area T. baccata inadequate. Matching the map of soil type with the final layer showed that $T$. baccata species has different distribution in different soil types.

\section{CONCLUSION}

Results showed that T. baccata species is sensitive to different factor changes and its distribution has direct relationship with ecological factors particularly climatic and physiographic factors (Mossadegh 1993, Salmanmahiny and Kamyab 2009). Also there is a high correspondence between the layer of $T$. baccata species preserves in the study site with the final produced layer of MCE and Boilan method. The results also showed that T. baccata has different ecological demands and it is possible to achieve good results by combining different layers. Also regarding the used factors and allocated weights by experts the differentiation between effective actors on T. baccata location has been confirmed. Using the results of this investigation it is possible to locate areas for $T$. baccata presence and to execute a plan in order to facilitate $T$. baccata plantation in northern forests of Iran (watershed 88). And at last regarding the evaluation using MCE and Bolian method it has been detect $T$. baccata location by dynamic ecological parameters the MCE method due to its hierarchy weighting (and not as appropriate and inappropriate) is more suitable than Bolian method.

\section{RESUMO}

Taxus baccata é uma espécie nativa das florestas do Cáspio e é considerada como a identificação dessas florestas por alguns recursos. $\mathrm{O}$ objetivo deste estudo foi compreender as características ecológicas de $T$. baccata visando encontrar áreas adequadas para seu cultivo no parque Pone 
Aram da província de Golestan. Para isto, foram utilizados métodos de avaliação de diferentes critérios baseados no processo hierárquico de análise. A princípio, neste processo os índices naturais necessários e eficazes foram usados como 10 parâmetros. Em seguida, o mapa final de áreas adequadas para o plantio de T. baccata foi produzido com base nos modelos de Bolian e MCE. De acordo com os resultados do modelo de Bolian, aproxidamente 6218 ha da área total do local de estudo (30.554ha) foram estimados como adequados e semi adequados e $24.336 \mathrm{ha}$ foram estimados como impróprios pelo modelo MCE. Isto mostrou que, de toda a área de estudo, 30.554ha, cerca de 2.482 são adequados para plantação de $T$. baccata e 6181ha não são adequados para o plantio de $T$. baccata. Considerando os resultados dos métodos de MCE e Bolian concluiu-se que, para os parâmetros ecológicos dinâmicos em delimitação de áreas adequadas para plantação de $T$. baccata plantação de MCE é mais apropriado do que de Bolian. Usando os resultados deste estudo, é possível adequar áreas para T. baccata e executar um plano para facilitar o plantio de T. baccata em florestas do norte do Irã (bacias hidrográficas 88).

Palavras-chave: Taxus baccata, localização, MCE, Bolian, Pone Aram, Irã.

\section{REFERENCES}

Ahmadi SANi N, Babaei Kafaki S AND MataJi A. 2011. Ecological Possibility of Ecotourism Activities in the Northern Zagros Forests Using MCDM, GIS and RS. Town and Country Planning 3(4): 45-64.

DANEHKAR A AND MAHMOODI B. 2008. Criteria and standards of ecotourism sites planning. National document of ecotourism. National ecotourism committee.
DARGAHI D. 2000. Ecological study on T. baccata in northern forests of Iran. PhD thesis, Tarbiat Modares University.

DELAVAR K. 1998. Investigating the effects of different environmental factors on taxol density in mature tree and tissue culture of T. baccata. MSc thesis, Tarbiat Modares University. (Unpublished).

EMAmi A, SHAMs ARdeKANI MR AND MeHregan I. 2004. Illustrated dictionary of medical plants. Traditional Medicine and Materia Medica Research Center, Shahid Beheshti University of Medical Sciences.

ESMAILZADEH O AND HoseINI SM. 2006. The relationship between plant ecological groups with plant biodiversity indices in Afra Takhte T. baccata preserve. J Environ Stud 33(43): 21-30.

GEOLOGICAL SURVEY OF IRAN. 2004. 1:100000 geological map of the country.

HABIBI KASEB HAND LESSANI MR. 1985. Investigation on soil and stand quality of T. baccata in Iran. Iran J Nat Resour 39: 13-27.

JAVANSHIR K. 1994. Coniferous. Research Institute of Forests and Rangelands 30: 547.

LESSANI MR. 1999. Yew T. baccata L. Research Institute of Forests and Rangelands. Technical Publication 210(1999): 71-73.

MossADEGH A. 1993. Yew tree. Research report of University of California, Berkeley.

PARHIZKAR A AND GHAFFARI GILANDEH A. 2006. Geographical information system and Multi-Criteria Evaluation. Samt Publication, $180 \mathrm{p}$.

PoORBABAEI H, JAVANSHIR K, MAKHDOOM M AND ZOBEIRY M. 1998. Common yew distribution and biodiversity with along wooden species of its stands in Gilan forests. J Environ Stud (21-22): 29-40.

SABETI H. 1994. Forests, trees and shrubs of Iran. Yazd University. $2^{\text {nd }}$ ed., p. 741-743.

SAlmanmahinY A AND KamYAB H. 2009. Applied remote sensing and GIS with Idrisi. Mehr Mahdis Publication, Tehran, p. 582.

VERDIAN RIZI MR. 2004. Extraction, Separation and purification of taxids existing in $T$. baccata branches. Doctor of Pharmacy thesis. Faculty of Pharmacy, Tehran University of Medical Sciences.

YAZDANI D, SHAHNAZI S, REZAZADEH SH AND PIR ALI HAMEDANI M. 2005. A review on T. baccata. J Med Plants 4(15): 1-8. 